\title{
disabled-1 Functions Cell Autonomously during Radial Migration and Cortical Layering of Pyramidal Neurons
}

\author{
Vicki Hammond, ${ }^{1}$ Brian Howell, ${ }^{2}$ Leanne Godinho, ${ }^{1}$ and Seong-Seng Tan ${ }^{1}$ \\ ${ }^{1}$ Howard Florey Institute, The University of Melbourne, Parkville 3010, Victoria, Australia, and ${ }^{2}$ National Institute for \\ Neurological Diseases and Stroke, National Institutes of Health, Bethesda, Maryland 20892
}

\begin{abstract}
Genetic mosaics offer an excellent opportunity to analyze complex gene functions. Chimeras consisting of mutant and wildtype cells provide not only the avenue for lineage-specific gene rescue but can also distinguish cell-autonomous from non-cellautonomous gene functions. Using an independent genetic marker for wild-type cells, we constructed $D a b 1^{+/+} \leftrightarrow D a b 1^{-/-}$ chimeras with the aim of discovering whether or not the function of Dab1 during neuronal migration and cortical layering is cell autonomous. Dab1 $1^{+/+}$cells were capable of radial migration and columnar formation in a $D a b 1^{-1-}$ environment. Most $D a b 1^{+/+}$cells segregated to the superficial part of the mutant cortex, forming a multilayered supercortex. Neuronal birthdating studies indicate that supercortex neurons were correctly layered, although adjacent mutant cortex neurons were in reversed order. Immunocytochemistry using Emx1, a marker for pyramidal neurons, indicates that the vast majority of $D a b 1^{+/+}$
\end{abstract}

neurons in the supercortex were Emx1 immunoreactive. Confirmation of the pyramidal phenotype was demonstrated by the absence of GABA immunoreactivity among $\mathrm{Dab} 1^{+/+}$cells in the supercortex. Myelin staining using 2' 3 '-cyclic nucleotide $3^{\prime}$ phosphodiesterase showed the supercortex was supported by a secondary white matter from which thick fiber tracts appear connected to the underlying mutant white matter. The presence of $\mathrm{Dab} 1^{+/+}$cells failed to rescue inversion of cortical layers and the abnormal infiltration of the marginal zone by $\mathrm{Dab} 1^{-/-}$cells. Conversely, mutant cells did not impose a mutant phenotype on adjacent wild-type neurons. These results suggest that Dab1 functions cell autonomously with respect to radial migration and cortical layering of pyramidal neurons.

Key words: disabled-1; Reelin; development; cortex; Emx-1; radial migration
Neurons that assemble to form the cerebral neocortex migrate in multiple waves after their birth in the ventricular zone. Earlyborn neurons are the first to reach the outermost aspects of the cortical plate $(\mathrm{CP})$, but these become displaced inward as laterborn neurons migrate past them (Angevine and Sidman, 1961; Rakic, 1974). In this manner, cohorts of neurons born at different times become organized into precise cortical layers. The genetic mechanisms behind this inside-out order of cortical layering have been under intense scrutiny, stimulated in part by the recent discovery of reelin, the gene responsible for the classic mouse mutant reeler (D'Arcangelo et al., 1995). Mutations in reelin give rise to inversion of cortical layers (Caviness and Sidman, 1973), in addition to other abnormalities in the hippocampus and cerebellum that are associated with the typical reeling gait and motor defects (Goldowitz et al., 1997). Whereas the Reelin protein is secreted by Cajal-Retzius cells in the marginal zone (MZ) (Ogawa et al., 1995; D'Arcangelo et al., 1997), neurons arriving into the adjacent CP are devoid of Reelin (Rice et al., 1998). Instead, CP neurons express a number of other proteins, some of which function downstream of Reelin (for review, see Rice and

\footnotetext{
Received Nov. 29, 2000; revised Aug. 9, 2001; accepted Aug. 16, 2001.

This work was supported by an Institute block grant from the National Health and Medical Research Council. We thank Frank Weissenborn for expert technical assistance, Rachael Parkinson and Renee Mason for making the chimeras, and Chris Job for stimulating discussions.

Correspondence should be addressed to Seong-Seng Tan, Developmental Neurobiology Laboratory, Howard Florey Institute, The University of Melbourne, Parkville 3010, Victoria, Australia. E-mail: stan@hfi.unimelb.edu.au. Copyright (C) 2001 Society for Neuroscience $0270-6474 / 01 / 218798-11 \$ 15.00 / 0$
}

Curran, 1999). Together, these proteins form the Reelin signaling pathway, and disruption of some of these components, either spontaneously or by gene-targeting, results in the reeler-like phenotype with behavioral ataxia and inversion of cortical layers (Howell et al., 1997b; Sheldon et al., 1997; Ware et al., 1997; Trommsdorff et al., 1999).

A key player in this molecular tapestry is disabled-1 (Dab1), a mouse relative of Drosophila disabled, that encodes an intracellular protein with properties of an adapter molecule in protein kinase signaling (Howell et al., 1997a). Dab1 lacks catalytic activity, but is required for Reelin signal transduction. After extracellular binding of Reelin to lipoprotein receptors [very lowdensity lipoprotein receptor (VLDLR) and apolipoprotein E receptor 2 (ApoER2)], increased tyrosine phosphorylation of Dab1 is observed (D'Arcangelo et al., 1999; Hiesberger et al., 1999; Howell et al., 1999). In addition, there is accumulation of Dab1 in cortical neurons of either reelin ${ }^{-1-}$ or ApoER2 $2^{-1-}$ / $V L D L R^{-1-}$ mice, suggesting failure of Dab1 degradation in the absence of Reelin pathway activation (Rice et al., 1998; Trommsdorff et al., 1999). The role for Dab1 tyrosine phosphorylation in Reelin signaling is further supported by mice that express a mutant form of Dab1 that is not a tyrosine kinase substrate. These mutant mice have a phenotype reminiscent of the Reeler mice and Dab1 null mutants, suggesting that correct Dab1 phosphorylation is a crucial event for correct neuronal positioning (Howell et al., 2000).

Apart from ApoER2/VLDLR receptors, Reelin has also been shown to bind to a number of other cell surface molecules present in migrating neurons, including cadherin-related neuronal receptors and $\alpha 3 \beta 1$ integrin (Senzaki et al., 1999; Dulabon et al., 2000). 
Mutations in a number of other genes also cause cortical laminar inversions (e.g., Cdk5 and p35) and abnormalities (e.g., $\alpha 3$ integrin), suggesting multiple pathway involvement in lamina formation and that components of the Reelin pathway, although necessary, may not be sufficient for layer specification. The question then arises whether the Reelin pathway, acting through Dab1, functions cell autonomously during two key morphogenetic processes involved in cortical development: cortical neuron migration and layer specification. If the answer is yes, then restoration of $D a b 1$ gene function by introducing $\mathrm{Dab} \mathrm{b}^{+/+}$cells into a $\mathrm{Dab1^{-/- }}$ environment should produce wild-type phenotypes in $D a b 1^{-1-}$ cells. In addition, there would be failure of rescue of mutant phenotypes among adjacent $D a b 1^{-/-}$neurons. Conversely, noncell-autonomous function of Dab1 would result in extension of gene function beyond cells expressing the original mutant phenotype, resulting in some $D a b 1^{+/+}$neurons assuming the mutant phenotype, although other $D a b 1^{-/-}$neurons may be rescued.

To distinguish between these possibilities, we constructed $\mathrm{Dab1}^{+/+} \leftrightarrow \mathrm{Dab1}^{-/-}$chimeras with the aim of undertaking lineage-specific gene rescue (Rossant and Spence, 1998). Using an independent lacZ marker for $\mathrm{Dabl}^{+/+}$cells, we found that $D a b 1^{+/+}$cells formed a supernumerary "supercortex" above the Dab1 $1^{-1-}$ cortex [not to be confused with the superplate (SPP) (Caviness, 1982)], and there was no rescue of layer inversion among adjacent $D a b 1^{-1-}$ neurons. Despite comprising a minority of cortical cells, the $D a b 1^{+/+}$neurons were able to form an inside-out cortical structure with respect to their birth dates. This structure bore some of the hallmarks of a "minicortex," including staining for the pyramidal neuron marker Emx1 and extensive myelination of a secondary subcortical white matter. These results led us to conclude that Dab1 signaling in cortical neurons is cell autonomous with respect to the establishment of cortical layers among radially migrating neurons of the pyramidal class.

\section{MATERIALS AND METHODS}

Chimeras. To generate $\mathrm{Dab1} 1^{+/+} \leftrightarrow \mathrm{Dab1}^{-/-}$chimeras $\left(\mathrm{Dab1} 1^{-/-}\right.$chimeras), we introduced embryonic stem (ES) cells carrying the lac $Z$ reporter gene into $D a b 1^{-1-}$ blastocysts. The latter were produced from $D a b 1^{+1-}$ heterozygous crosses (maintained on C57BL/6J $\times$ DBA hybrid background), and $D a b 1^{-1-}$ offspring were identified by genotyping. The ES cells have normal Dab1 alleles (confirmed by PCR) and were derived from the H253 transgenic mouse line with the $\mathrm{X}^{\text {lacZ }} / \mathrm{X}^{\text {lacZ }}$ genotype (Tan et al., 1993; Sturm et al., 1997). Previous experiments using this cell line have shown that the injection of one to two ES cells per blastocyst is sufficient to confer chimerism in the CNS, and the genetically marked cells migrated in essentially the same patterns as host cells (Tan et al., 1998; Reese et al., 1999). Injected blastocysts were implanted into pseudopregnant foster females, and chimeric pups were reared for 14-16 d before genotype analysis and processing for 5-bromo-4-chloro-3-indolyl$\beta$-D-galactopyranoside (X-gal) histochemistry and immunocytochemistry. For immunocytochemistry against Dab1 and calretinin [a marker for the subplate (SP)], a number of embryos $(n=33)$ were killed at embryonic day 16.5 (E16.5), and brains were fixed as whole mounts in a solution of $4 \%$ paraformaldehyde.

To test whether $D a b 1^{+/+}$and $D a b 1^{-/-}$neurons migrate correctly in the chimeric cortices, mice were treated in utero (at gestational ages E12.5, E13.5, or E16.5) with 5-bromodeoxyuridine (BrdU) at a dose of 50 $\mathrm{mg} / \mathrm{kg}$ body weight (intraperitoneally, dissolved in sterile saline containing $0.007 \mathrm{~N} \mathrm{NaOH}$ ). Neurons retaining the BrdU label are presumed to have been born during the labeling period, when they undergo the last $S$ phase of their mitotic cycle.

Genotyping. To isolate DNA for PCR genotyping, tissue (toe, tail, liver, or lung) was digested in $200 \mu \mathrm{l}$ of PCR lysis buffer $(50 \mathrm{~mm} \mathrm{KCl}, 10$ $\mathrm{mm}$ Tris- $\mathrm{HCl}$, pH 8.3, 2 mM $\mathrm{MgCl}_{2}, 0.45 \%$ Nonidet P-40, and $0.45 \%$ Tween 20) with Proteinase $\mathrm{K}(200 \mu \mathrm{g} / \mathrm{ml})$ at $56^{\circ} \mathrm{C}$. DNA primers were used at a final reaction concentration of $10 \mathrm{ng} / \mu \mathrm{l}$. Primers for Dab1 covering the deleted portion of the gene (Howell et al., 1997b) and for neomycin phosphotransferase (Neo) gene were used (Dab1: forward,
5'GCGAAGCCACTTTGATAAAGA-3' and reverse, 5'-TAACTTGTCTCCCCGAGCTG-3';Neo:forward, 5'-ATCAGGATGATCTGGACGAAGA-3' and reverse, 5'-CCACAGTCGATGAATCCAGAA-3'). Primer sequences for $l a c Z$ were as follows: forward 5'-CCCATTACGGTCAATCCGCCG-3', and reverse 5'-CCTGGCCGTAACCGACCCAGCG-3').

The DNA-primer mixture was heated at $94^{\circ} \mathrm{C}$ for $10 \mathrm{~min}$ in a Gene Amp PCR System (model 9600, PerkinElmer Life Sciences, Emeryville, CA). A reaction mix was then added to give a final concentration of 100 mm Tris-HCl, pH 8.3, 500 mm KCl (1× PCR Buffer II; PerkinElmer Life Sciences), $1.5 \mathrm{~mm} \mathrm{MgCl} 2,100 \mu \mathrm{M}$ dNTPs, and $1.25 \mathrm{U}$ of Taq DNA polymerase (PerkinElmer Life Sciences). Amplification of the samples was performed by an additional $1 \mathrm{~min}$ at $94^{\circ} \mathrm{C}$, followed by 36 cycles consisting of annealing at $62^{\circ} \mathrm{C}$ for $30 \mathrm{sec}$, extension at $72^{\circ} \mathrm{C}$ for $30 \mathrm{sec}$, and denaturing at $94^{\circ} \mathrm{C}$ for $30 \mathrm{sec}$. PCR products were analyzed on a $3 \%$ agarose gel with anticipated 81, 170, and 154 bp product sizes for Dab1, $N e o$, and $l a c Z$, respectively.

Histology. After a lethal injection of Avertin, chimeras were perfused for $15 \mathrm{~min}$ by intracardial perfusion with $4 \%$ paraformaldehyde in $0.1 \mathrm{M}$ Sorensen's phosphate buffer, $\mathrm{pH} 7.4$, with $2 \mathrm{mM} \mathrm{MgCl}_{2}$ and 5 mM EGTA, and the brains were removed for $20 \mathrm{~min}$ after fixation. After cryoprotection with $30 \%$ sucrose, brains were embedded in OCT (Tissue-Tek, Miles Inc., Torrance, CA) for cryosectioning. Coronal sections $(60 \mu \mathrm{m})$ of the cortex were obtained for X-gal histochemistry to visualize $\beta$-galactosidase $(\beta \mathrm{gal})$, and $14 \mu \mathrm{m}$ coronal sections were prepared for immunocytochemistry. Sections for X-gal histochemistry were incubated overnight at $37^{\circ} \mathrm{C}$ in a solution of $0.1 \% \mathrm{X}$-gal containing $2 \mathrm{~mm} \mathrm{MgCl}, 5$ mM EGTA, $0.01 \%(w / v)$ sodium deoxycholate, $0.02 \%(w / v)$ Nonidet $\mathrm{P}-40,5 \mathrm{mM} \mathrm{K}_{3} \mathrm{Fe}(\mathrm{CN})_{6}$, and $5 \mathrm{mM} \mathrm{K}_{4} \mathrm{Fe}(\mathrm{CN})_{6} \cdot 6 \mathrm{H}_{2} \mathrm{O}$ in $0.1 \mathrm{M}$ Sorenson's phosphate buffer. The X-gal was prepared as a $4 \%$ stock in dimethylformamide and was added to the mixture just before use.

For nuclear staining after X-gal histochemistry, sections were rinsed in PBS and then stained in $50 \mu \mathrm{g} / \mathrm{ml}$ Hoescht 33342 (Sigma, St. Louis, MO) for $2 \mathrm{~min}$. Fluorescent cell nuclei were visualized using a UV filter.

Immunocytochemistry. For double-immunofluorescence studies, $14 \mu \mathrm{m}$ coronal sections were mounted on 3-aminopropyltreithoxy-silane-coated slides and dried for $2 \mathrm{hr}$ before incubating in primary antibodies. To obtain double labeling of $\beta$ gal with BrdU, NeuN, calbindin, or 2' 3 '-cyclic nucleotide $3^{\prime}$-phosphodiesterase (CNPase), sections were processed for immunocytochemistry using either standard one-step or two-step avidin-biotin procedures. To expose the BrdU, tissues were preincubated with $2 \mathrm{~N} \mathrm{HCl}$ at $37^{\circ} \mathrm{C}$ for 45 min before addition of the primary antibody. All primary antibodies were diluted in $0.1 \mathrm{M}$ PBS with $0.3 \%$ Triton $\mathrm{X}-100$. Primary antibodies included the following: a purified rabbit polyclonal antibody to $\beta$ gal $(1: 100$ dilution; 5 Prime $\rightarrow 3$ Prime Inc., Boulder, CO); a mouse monoclonal antibody to $\beta$ gal (1:250 dilution; Promega, Melbourne, Australia); a mouse monoclonal antibody to BrdU (1:30 dilution; Becton Dickinson, San Jose, CA); a mouse monoclonal antibody to NeuN (1:200 dilution; Chemicon, Temecula, CA); a mouse monoclonal antibody to CNPase (1:200 dilution; Chemicon); a rabbit antibody to calretinin (1:200 dilution; Swant, Bellinzona, Switzerland); a rabbit polyclonal antibody to calbindin (1:1000 dilution; Swant); and a rabbit polyclonal antibody to Dab1 (Howell et al., 1997a). Secondary antibodies were biotinylated anti-rabbit (1:200 dilution; Vector Laboratories, Burlingame, CA), donkey anti-mouse Cy3 (1:1000 dilution; Jackson ImmunoResearch, West Grove, PA), and Alexa Fluor 594conjugated goat anti-rabbit IgG (1:500 dilution; Molecular Probes, Eugene, OR). With BrdU, NeuN, and CNPase antigens, simultaneous visualization of $\beta \mathrm{gal}$ was achieved with fluorescein-avidin D (1:200 dilution; Vector Laboratories). Incubation with primary antibody overnight was followed by $1 \mathrm{hr}$ in secondary antibodies before coverslipping with Fluoromount-G (Southern Biotechnology, Birmingham, AL).

For simultaneous detection of $\beta \mathrm{gal}$ and Emx1 or $\beta \mathrm{gal}$ and GABA, we used a method that allows discrimination of primary antibodies raised in the same species, in this case the rabbit (Shindler and Roth, 1996). This method works on the rationale that primary antisera against one antigen (Emx1 or GABA) is used at such dilute levels that only tyramide signal amplification (TSA) allows for its detection. The second primary antiserum against $\beta \mathrm{gal}$ is used at normal concentration and is detected by conventional immunocytochemistry. The secondary antibody used to detect the rabbit IgG against $\beta$ gal is incapable of detecting the rabbit IgG against Emx1 (or GABA) by virtue of the extreme dilution of the latter.

Sections were blocked in 10\% normal horse serum (CSL Ltd., Melbourne, Australia) in PBS for $1 \mathrm{hr}$ and then in $0.5 \%$ blocking reagent (Renaissance TSA Indirect; NEN, Boston, MA) in buffer containing 0.1 
Figure 1. Genotyping to distinguish chimeric from nonchimeric animals and wild-type from mutant animals. $A$, Top band represents the mutant allele (Neo 170bp), and the bottom band the endogenous allele (Dab1 81bp). $B$, Top band represents lac $Z$ from introduced ES cells (LacZ 154bp), the bottom band represents Dab1 (81 bp). Lane 1, pUCHpaII markers; lane 2, homozygous mutant $\left(\right.$ Dab1 $\left.1^{-1-}\right)$; lane 3 , heterozygous mutant $\left(D a b 1^{+-}\right)$; lane 4, wild type $\left(D a b 1^{+/+}\right)$; lane 5, weak $D a b 1^{-1-}$ chimera; lanes 6-9, strong Dab1 ${ }^{-1-}$ chimeras; lane 10, injected ES cells; lane 11, no DNA. As expected, a weak $D a b 1^{-1-}$ chimera gave a strong Neo band and a weak Dab1 band (lane 5); conversely, strong Dab1 $1^{-1-}$ chimeras (lanes 6-9) gave intense Dab1 signals from the ES cell allele. Confirmation of the presence of the injected ES cells was obtained by assaying for the presence of the lac $Z$ gene. As expected, this band was present in the ES cells (lane 10) and in chimeras (lanes 5-9).
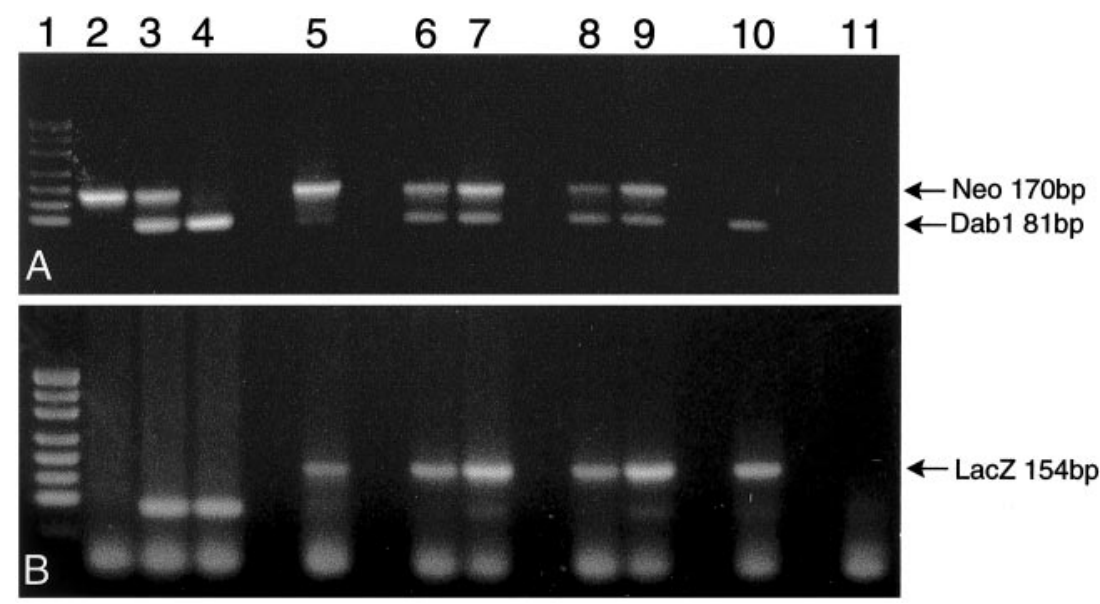

$\mathrm{M}$ Tris- $\mathrm{Cl}$ and $0.15 \mathrm{M} \mathrm{NaCl}, \mathrm{pH} 7.6$, for $30 \mathrm{~min}$ at room temperature. Incubation with rabbit anti-Emx1 (1:6000 dilution; gift of J. Parnavelas, University College, London, UK) or rabbit anti-GABA (1:10,000 dilution; Sigma, St. Louis, MO) was performed overnight, followed by biotinylated goat anti-rabbit IgG (1:200 dilution; Vector Laboratories) and streptavidin-HRP (Renaissance TSA Indirect; diluted 1:100; NEN) for $1 \mathrm{hr}$. This was followed by biotinyl tyramide amplification for $2 \mathrm{~min}$ (1:100 dilution; amplification diluent) and incubation for $1 \mathrm{hr}$ in fluorescein-avidin D (1:200 dilution; Vector Laboratories). Detection of $\beta$ gal was essentially as described above, except that the secondary fluorophore was substituted with Alexa Fluor 594 goat anti-rabbit IgG (diluted 1:400; Molecular Probes). Sections were mounted with Fluoromount-G (Southern Biotechnology, Birmingham, AL).

\section{RESULTS}

Previous studies using stem cell chimeras have shown that descendants of a single injected ES cell are capable of normal participation in CNS development and provide good resolution on cell migration pathways and cell fates (Tan et al., 1998; Hawkes et al., 1999; Reese et al., 1999). Using this model, we introduced one to two wild-type ES cells into blastocysts from $D a b 1^{+/-}$intercrosses. Under these conditions, ES cells with normal Dab1 genes can populate blastocyst hosts with $D a b 1^{-/-}$, $D a b 1^{+/-}$, or $D a b 1^{+/+}$genotypes.

Chimeras (from $\mathrm{Dab1}^{-/-}, \mathrm{Dab1^{+/- }}$, or $\mathrm{Dab1^{+/+ }}$ hosts) were identifiable by their patchy coat colors, and $D a b 1^{-1-}$ chimeras (subsequently confirmed by genotyping) displayed ataxia, trembling, dragging of hind limbs, and frequent flipping onto their backs. In all $\mathrm{Dab1} 1^{-1-}$ chimeras, regardless of the contribution of wild-type cells to their brains, this behavioral phenotype was not rescued, and these mice did not survive beyond $17 \mathrm{~d}$ after birth. In all cases, chimeric cerebella were smaller and poorly foliated. Genotyping results were used to distinguish $D a b 1^{-1-}$ chimeras from littermates. Nonchimeric mice did not provide a PCR product for lacZ (Fig. 1B, lanes 2-4). The presence or absence of $D a b 1$ or Neo fragments allowed wild-type $\left(D a b 1^{+/+}\right)$hosts (Fig. $1 A$, lane 4$)$ to be distinguished from heterozygous $\left(D a b 1^{+/-}\right)$ (lane 3) or null $\left(D a b 1^{-1-}\right)$ (lane 2) mutants. Weak Dab1 $1^{-1-}$ chimeras (lane 5) tended to provide a weaker Dab1 band (from the smaller contribution of ES cells) but a strong band for the Neo gene present in the targeting construct (Howell et al., 1997b). Strong $\mathrm{Dab1}^{-1-}$ chimeras (lanes 6-9) gave bands of approximately equal intensity for Dabl and Neo, reflecting a greater contribution of $\mathrm{Dabl}^{+/+}$ES cells. Lane 10 shows the presence of Dab1 in ES cells used for making the chimeras.

\section{Wild-type cells in Dab1 ${ }^{-/-}$chimeras form a supercortex}

Chimeric littermates with $\mathrm{Dab1} 1^{+/+}$or $\mathrm{Dab1} 1^{+/-}$genotypes were used as controls for studying cortical cell dispersion. In these mice, $\beta$ gal-expressing cells in the neocortex exhibited cell dispersion patterns seen in normal chimeras (Tan et al., 1998). Radial columns of cells extending across the full cortical depth were seen in $\mathrm{Dab1} 1^{+/-}$chimeras, suggesting that wild-type neurons migrate normally, despite an environment of cells heterozygous for $D a b 1$ (Fig. $2 A$ ). In contrast, the distribution of wild-type cells in $\mathrm{Dab}^{-1-}$ chimeras was unexpected, with ectopic segregation of $\beta$ gal-positive cells mainly in the superficial area and occupying a cortical rind beneath the pial surface (Fig. 2B, arrows). Deeper into the cortex, a minor but still substantial fraction of $\beta$ galpositive cells was diff usely intermingled with $\mathrm{Dab1}^{-/-}$cells, making up the bulk of the cortical tissue underneath the densely packed wild-type cells (Fig. $2 B, D$ ). Despite the uneven distribution, the $\beta$ gal-positive cells in both deep and superficial areas appeared to share a radial dispersion pattern with parallel registration of lateral boundaries (Fig. $2 B$, inset). In strong chimeras, radial columns were not visible, probably because of the merging of neighboring columns (Fig. $2 C, D$ ). All Dab1 $1^{-/-}$chimeras displayed the intense packing of $\beta$ gal-positive $D a b 1^{+/+}$cells into a dense superficial band, resembling a supernumerary cortex that we termed a supercortex (Fig. $2 C, D$ ). $D a b 1^{-1-}$ cells appeared to fill the remaining cortical thickness with a non-uniform infiltration of $\mathrm{Dab1} 1^{+/+}$cells, some of which coalesced into cellular nodules in the middle layers (Fig. $2 C$, white arrows). Interestingly, the supercortex did not extend beyond the entorhinal areas (Fig. $2 C$, arrowheads). The normally cell-poor MZ, situated above the supercortex, was invaded by a large number of cell bodies, similar to that reported for mice lacking Reelin, Dab1, or ApoER2/ VLDLR. Cells of both genotypes were found in the MZ (Fig. $2 D-F$ ), although staining of cell nuclei with Hoescht 33342 (Fig. $3 F$ ) revealed that the vast majority of the infiltrate were $D a b 1^{-1-}$ cells. Thus, despite the presence of adjacent wild-type cells, a large number of mutant cells continued to invade the $\mathrm{MZ}$ as reported previously (Howell et al., 1997b).

\section{Dab1 ${ }^{+/+}$cells in the supercortex are Emx1-positive pyramidal neurons}

To ascertain the identity of the cells making up the supercortex, we performed double-immunofluorescent experiments using antibodies against $\beta$ gal and NeuN, a marker for neurons. The results 

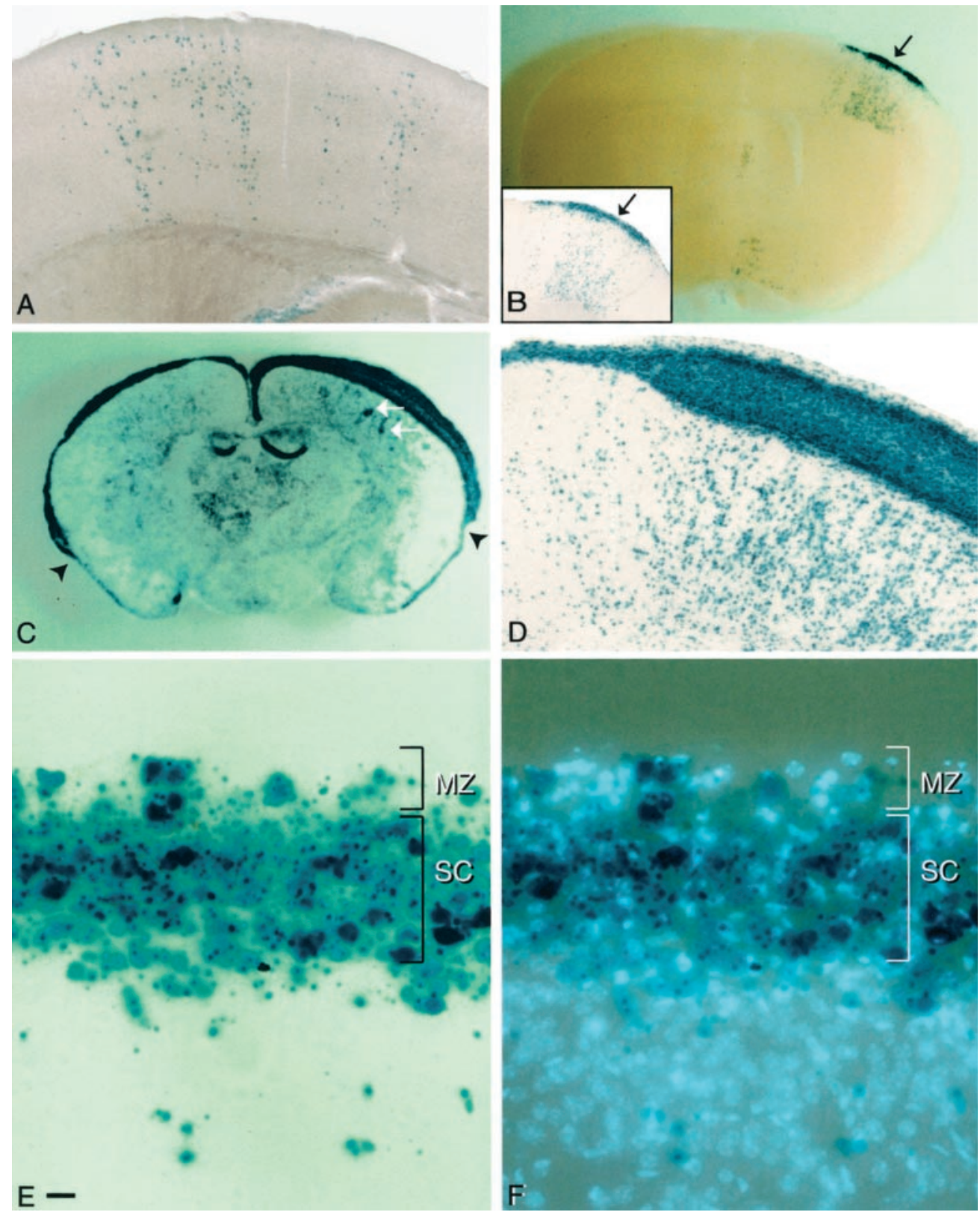

Figure 2. $\mathrm{Dab1}^{+/+}$cells in chimeras form a supercortex $(S C)$ beneath the pial surface. $A$, Radial columns are formed by $\beta$ gal-positive cells $\left(D a b 1^{+/+}\right.$ genotype), despite being in a heterozygous $D a b 1^{+/-}$cortical environment. $B$, In $D a b 1^{-1-}$ chimeras, $\beta$ gal-positive cells have formed a column in this weak chimera, with the majority of the $D a b 1^{+/+}$ cells segregating to the superficial aspects of the column (arrows). $C$, In this strong $D a b 1^{-1-}$ chimera, the superficial layers are occupied by densely packed $\mathrm{Dab1}^{+/+}$cells, which formed a supercortex on top of the mutant cortex. The lateral reaches of the supercortex appear to terminate at the entorhinal region (arrowheads). Note a white band in the supercortex that corresponds to the position of normal layer $\mathrm{V}$ neurons. Deeper down in the mutant cortex, other $D a b 1^{+/+}$cells are found in smaller clusters (white arrows). D, At higher magnification, the supercortex is situated beneath the MZ. Other $\beta$ galpositive cells are also seen in mutant cortical tissue beneath the supercortex. $E$, Higher magnification of strong Dab1 ${ }^{-1-}$ chimera shows invasion of $\mathrm{Dab1}^{+/+}$cells into the adjacent MZ. F, Nuclear staining with Hoescht dye reveals a cell-rich MZ, made up mainly by Dab1 ${ }^{-1-}$ cell bodies (light blue), with a smaller number of $\mathrm{Dab1}^{+/+}$cells (dark blue). Scale bar: $A, 145 \mu \mathrm{m} ; B, 455 \mu \mathrm{m}$; inset in $B, 310 \mu \mathrm{m} ; C, 510 \mu \mathrm{m} ; D, 110$ $\mu \mathrm{m} ; E, F, 16 \mu \mathrm{m}$. indicate widespread immunoreactivity for $\mathrm{NeuN}$ (Fig. $3 A$, red and double-labeled, yellow, or orange), with only a few cells expressing $\beta$ gal (green) without NeuN (Fig. 3A). Doubleimmunofluorescence was also performed using antibodies against $\beta$ gal and Emx1, a homeoprotein transcription factor homologous to the product of the Drosophila gene empty spiracles (Cecchi and Boncinelli, 2000). Emx1 has been shown to label cortical neurons (Gulisano et al., 1996) and, more specifically, to be a marker for pyramidal neurons (Chan et al., 2001). Widespread staining for Emx1 was confirmed across the entire cortex (Fig. 3B, green and double-labeled, yellow, or orange), but in the supercortex, most of the cells were doublelabeled with $\beta$ gal and Emx1 (Fig. $3 B-D$ ). At the bottom layer of the supercortex and parallel to the pia (Fig. $3 B, C$, dotted lines), a string of weakly positive Emx1 cells were found (Fig. $3 D$, arrows). The identity of these remain unclear; however, their large cell somas and immunoreactivity for NeuN suggests they are neurons. Within the supercortex, a small number of
Emx1-positive but $\beta$ gal-negative (i.e., $D a b 1^{-/-}$) cells were also found, indicating contribution by host mutant cells. In the MZ overlying the supercortex, wild-type $\beta$ gal-positive cells were also found, although very few of these were weakly stained for Emx1 (Fig. 3B).

To confirm that Emx1 is a marker for radially migrating neurons, we performed double-immunofluorescent labeling on radial columns of wild-type chimeras. Staining with $\beta$ gal-antibody revealed the columnar arrangement of lacZ-expressing cells (Fig. $3 E$, red); however, staining with anti-Emx1 showed that, without exception, all of the cells comprising the column also stained for Emx1 (Fig. $3 F$, yellow or orange). In light of previous studies that have showed that radially migrating cells are predominantly glutamatergic (Tan et al., 1998), coupled to electron microscopic evidence that Emx1 only marks pyramidal neurons (Chan et al., 2001), these results suggest that the Emx1-positive cells in the supercortex are pyramidal. Additional supporting evidence was obtained using antisera directed against GABA, a marker for 
nonpyramidal interneurons. In the supercortex (Fig. 3G), $\beta$ galpositive cells (red) rarely stained for GABA (green), but in the mutant cortex, double-positive cells (green with yellow center) were found (Fig. 3G, arrows). Although GABA-positive neurons were seen in the supercortex (Fig. 3G, arrowheads), they were invariably $\mathrm{Dab1}^{-/-}$(green). Thus, it would appear that wild-type GABA interneurons, which normally have a tangential mode of cell dispersion and the bulk of which originate from the underlying ganglionic eminence (Anderson et al., 1997, 2001), did not contribute to the formation of the supercortex.

\section{Supercortex is linked to mutant white matter by myelinated fibers}

The myelin-associated enzyme CNPase is normally found in the plasma membrane of oligodendrocytes (Sprinkle, 1989; Thompson, 1992). In the normal cortex, CNPase immunoreactivity is associated with myelin-producing cells found in deeper layers and also in the subcortical white matter (Vogel et al., 1988). This pattern of CNPase staining was confirmed in wild-type and Dab1 $1^{-/-}$cortices (Fig. 4A,B, arrows), with occasional and faint fibrillar staining within the lower cortical layers (arrowheads). In addition, oblique fiber bundles were sporadically observed within the mutant cortex. The superficial cortical layers clearly lacked significant immunoreactivity, with the exception of slight increased staining where the $\mathrm{MZ}$ normally resides in the $D a b 1^{-/-}$ cortex (asterisk).

In contrast, the cortex of $D a b 1^{-1-}$ chimeras displayed a striking picture of CNPase immunoreactivity (Fig. 4C). Intense labeling, suggestive of widespread myelination, was observed beneath the supercortex in a horizontal fiber tract running parallel to the supercortex (Fig. 4C, arrow). Many of the fibers had coalesced to form thick bundles. Intense immunoreactivity was also observed in the white matter and also in vertical fiber bundles traversing the Dab1 $1^{-1-}$ cortex. These vertical fiber bundles appeared to link the subcortical fiber tracts beneath the supercortex with mutant white matter (Fig. 4C, arrowheads). The supercortex per se was remarkably free from myelin staining, except for a thin margin of occasional immunoreactivity in the superficial pial region and also in the deeper layers of the supercortex. Because CNPase expression and activity is dependent on the presence of nerve axons (Goto et al., 1990), it is reasonable to assume that CNPase activity is associated with nerve fiber tracts occupying a "white matter" region beneath the supercortex. In this scenario, the vertical bundles of myelinated tracts may represent nerve fibers attempting to connect the supercortex with other subcortical structures. Indeed, the intensity of staining in white matter of $D a b 1^{-/-}$chimeras greatly exceeds that of either wild-type or $D a b 1^{-/-}$mutants, suggesting an increased number of myelinated fibers (Fig. 4C). However, it remains unclear whether fiber tracts from the supercortex are functional as corticofugal fibers emanating from supercortical neurons or corticopetal pathways innervating the supercortex.

So far, neurons in the supercortex have been shown to be exclusively pyramidal in composition by virtue of positive staining for Emx1 and negative for GABA. Pyramidal neurons in the supragranular layers have been shown to be differentially stained for calbindin, a calcium binding protein (Demeulemeester et al., 1989; van Brederode et al., 1991). Antibodies revealed calbindin immunoreactivity only among neurons present in the upper half of the supercortex (Fig. 4D, yellow and arrows), whereas the lower half supercortex neurons stained only for $\beta$ gal (Fig. 4D, red). Other calbindin-positive neurons with extensive processes but belonging to the host $D a b 1^{-/-}$population were also seen beneath the supercortex, and their morphology suggests them to be mutant interneurons (Fig. 4D, green).

\section{A subplate is formed beneath the supercortical plate}

The calcium-binding protein calretinin labels the marginal zone and subplate, derivatives of the preplate, at specific developmental stages (Vogt-Weisenhorn et al., 1994; Fonseca et al., 1995). Using an antibody to calretinin, the cortices of E16.5 (wild-type, $D a b 1^{-1-}$ mice, and $D a b 1^{-1-}$ chimeras) were immunostained to examine for the presence and localization of the subplate. In wild-type cortices, both the MZ and the SP were labeled (Fig. $5 A$, arrows), whereas in $D a b 1^{-/-}$brains, the unsplit preplate known as the SPP was labeled for calretinin (Fig. $5 B$, arrow). Dab1 $1^{-1-}$ chimeras displayed an interesting pattern of staining: a strong band of calretinin staining was seen in the presumptive MZ (Fig. $5 D$, arrow), but in addition, there was clearly a string of calretininpositive subplate cells underneath the "supercortical" plate (Fig. $5 D$, arrow). The location of the supercortical plate in these sections was identified by examining neighboring sections immunostained for $\beta$ gal (Fig. $5 C$, asterisk). These results suggest that the supercortical plate has been positioned between the MZ and SP. The genotype of the SP in $D a b 1^{-1-}$ chimeras revealed a mixture of both mutant and wild-type cells (our unpublished observations).

\section{Dab1 is expressed in $\boldsymbol{\beta g a l}$-positive cells}

In $D a b 1^{-1-}$ chimeras, wild-type cells of ES cell origin are distinguished by expression of the lac $Z$ marker. To confirm that wildtype cells express Dab1, we performed immunostaining using antibodies to Dab1 and $\beta g a l$ on adjacent sections of E16.5 neocortices. At this stage, the "cortical plate" of the future supercortex can be identified as a $\beta g a l$-positive structure underneath the pial surface (Fig. 5E, asterisk). Staining of the adjacent section revealed the presence of Dab1 protein in the supercortex (Fig. $5 F$, asterisk), but as expected, not in the underlying Dab1 ${ }^{-/-}$host.

\section{Neurons of the supercortex are born in the correct inside-out order}

A key hallmark of defective Reelin signaling is the inversion of cortical neurons born at different times of the neuronogenetic period (Caviness, 1982). The thymidine analog BrdU was used to label neurons undergoing the last round of mitotic cell division, before their migration to the CP. Neuronal birth dating was performed for wild-type, mutant $\mathrm{Dabl}^{-1-}$ (nonchimeric), and $\mathrm{Dab1}^{-1-}$ chimeras to compare the positions of neurons labeled with BrdU. In the nonchimeric Dab1 $1^{-/-}$cortex, BrdU labeling at E12.5 and E13.5 confirmed aberrant displacement of early-born cohorts to superficial layers (Howell et al., 1997b) (Fig. 6B, arrows). As expected in the wild type, superficial layer labeling was observed after BrdU injection at E17.5 (Fig. 6A). In Dab1 $1^{-/-}$ chimeras, BrdU injection at E16.5 showed labeling of $\mathrm{Dab1} 1^{+/+}$ neurons (yellow) in the upper layers of the supercortex (Fig. 6C, arrows), which is compatible with the expected labeling position of later-born neurons. The host BrdU-labeled $\mathrm{Dab1}^{-1-}$ neurons were mostly distributed in the deeper half of the mutant cortex (data not shown), as reported by others (Howell et al., 1997b), but in the supercortex, a very small number of $D a b 1^{-/-}$cells could also be found close to the pial surface (Fig. $6 \mathrm{C}$, red). Additional confirmation that layers are inverted in the mutant cortex is provided by the relative absence of E16.5 BrdU-labeled cells in the area directly beneath the supercortex (Fig. 6C). Dab1 $1^{-1-}$ chimeras were also injected with BrdU at E12.5, and early born 

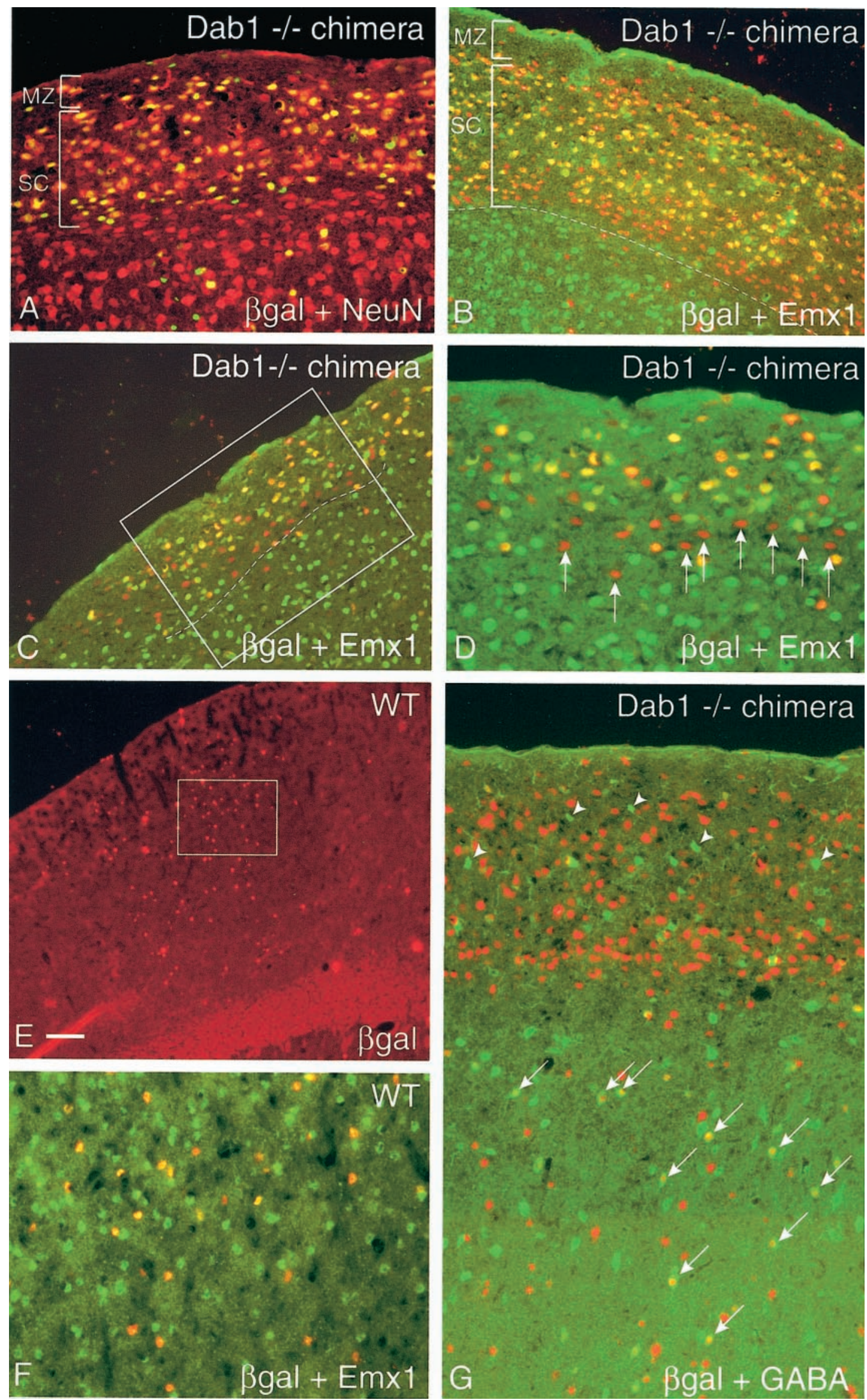
Figure 4. The supercortex is supported by extensive myelination of its undersurface. $A$, In wild-type $(W T)$ neocortex, CNPase immunoreactivity is confined to the white matter ( $W M$, arrow), with occasional staining of fibers (arrowheads) within the gray matter. $B$, In $D a b 1^{-1-}$ neocortex, CNPase staining is present in the white matter (arrow) but is also increased in the superficial region (asterisk) beneath the pial surface. In addition, sporadic myelin staining is also found within the gray matter (arrowheads). $C$, In the neocortex of $\mathrm{Dab1}^{-1-}$ chimeras, CNPase staining is found underneath the supercortex (arrow) and also marking myelinated fiber bundles (arrowheads) connecting the supercortex with the mutant white matter. Note increased packing of $\beta g a l$-positive (green) cells in the supercortex. $D$, In the supercortex (bracket), cells in the upper layers only are immunoreactive for calbindin ( yellow, arrows), whereas lower layer cells stained only for $\beta g a l$ (red). Mutant calbindin-positive neurons in the mutant cortex (green) appear to possess branching morphologies, suggestive of interneurons. Scale bar: $A-C, 75 \mu \mathrm{m} ; D, 40 \mu \mathrm{m}$.
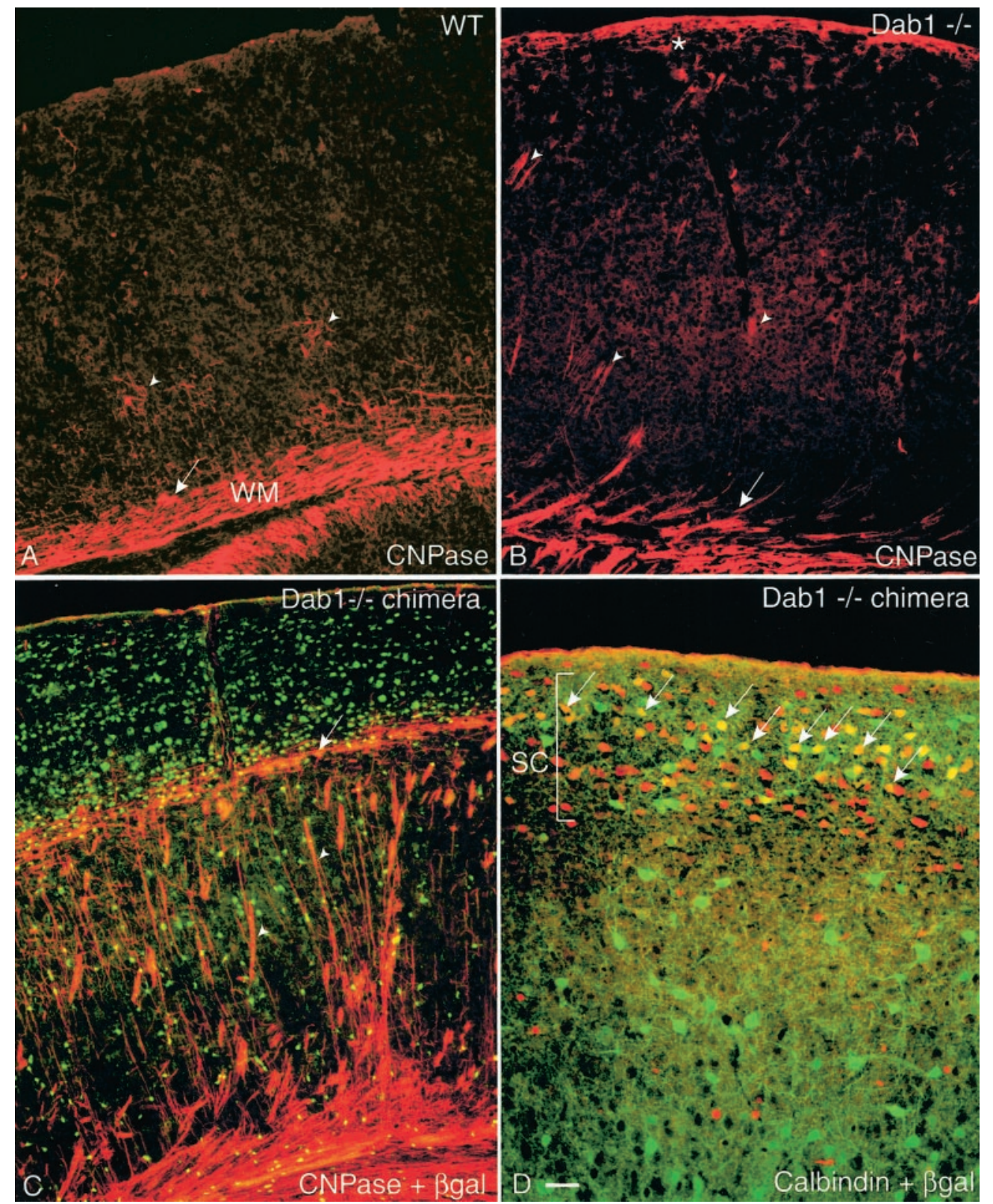

Dab1 $1^{+/+}$neurons (yellow) were found in the deeper layers of the supercortex (Fig. 6D, arrows). In these brains, the early-born mutant neurons (red) were mostly found in the upper part of the mutant cortex, situated just beneath the supercortex (Fig. 6D, red). A low-power view showed that BrdU cells of Dab1 $1^{-1-}$ genotype (Fig. 6E, arrows), labeled at E12.5, had migrated to the upper one-third of the mutant cortex, suggesting persistent layer inversion of the mutant cells, despite the presence of the $D a b 1^{+/+}$ supercortex above. Thus, $D a b 1^{+/+}$neurons born at different times in the chimeric cortex appear to migrate to the appropriate deep and superficial layer positions within the supercortex. Together with the calbindin-staining data (Fig. 4D), neuronal positioning of $\mathrm{Dab1}^{+/+}$cells in the supercortex appears to be independently driven and correlated with their Dabl genotype.

\section{DISCUSSION}

Classically, the first step toward elucidation of gene function is by targeted gene deletion. In the case of Dab1, the spontaneous

Figure 3. $\quad \mathrm{Dab}^{+/+}$cells in supercortex are mainly pyramidal neurons. $A$, Double-labeling for $\beta g a l$ (green) and NeuN (red) reveals that the vast majority

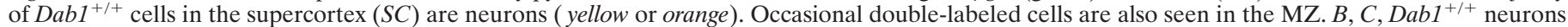
in the supercortex are double-labeled for $\beta g a l$ (red) and Emx1 (green). With little exception, all $\beta g a l$-positive cells also express Emxl (yellow or orange). In the overlying MZ, a small number of $\beta g a l$-positive (but Emxl-negative) cells may be seen. Note a row of $\beta g a l$-positive cells (red) but weakly expressing Emx1 lining the bottom of the supercortex (dotted white lines). D, Higher magnification of boxed area in $C$ showing $\beta g a l$-positive cells (arrows) weakly immunoreactive for Emx1. E, A column of $\beta g a l$-positive cells $($ red $)$ found in a normal wild-type chimera. $F$, Higher magnification of boxed area in $E$ showing double-labeling for $\beta g a l$ (red) and Emx1 (green). Without exception, all Bgal-positive cells in the column also costain for Emx1 (yellow or orange), a marker for pyramidal neurons. $G$, Double-immunofluorescence for $\beta g a l$ (red) and GABA (green) in Dab1 ${ }^{-/-}$chimera reveals that double-positive cells (green with yellow center, arrows) are almost always found below the supercortex. Within the supercortex, GABA-positive cells (green, arrowheads) are invariably $D a b 1^{-1-}$ in genotype. Scale bar: $A, G, 50 \mu \mathrm{m} ; B, 65 \mu \mathrm{m} ; C, 55 \mu \mathrm{m} ; D, 30 \mu \mathrm{m} ; E, 200 \mu \mathrm{m} ; F, 40 \mu \mathrm{m}$. 

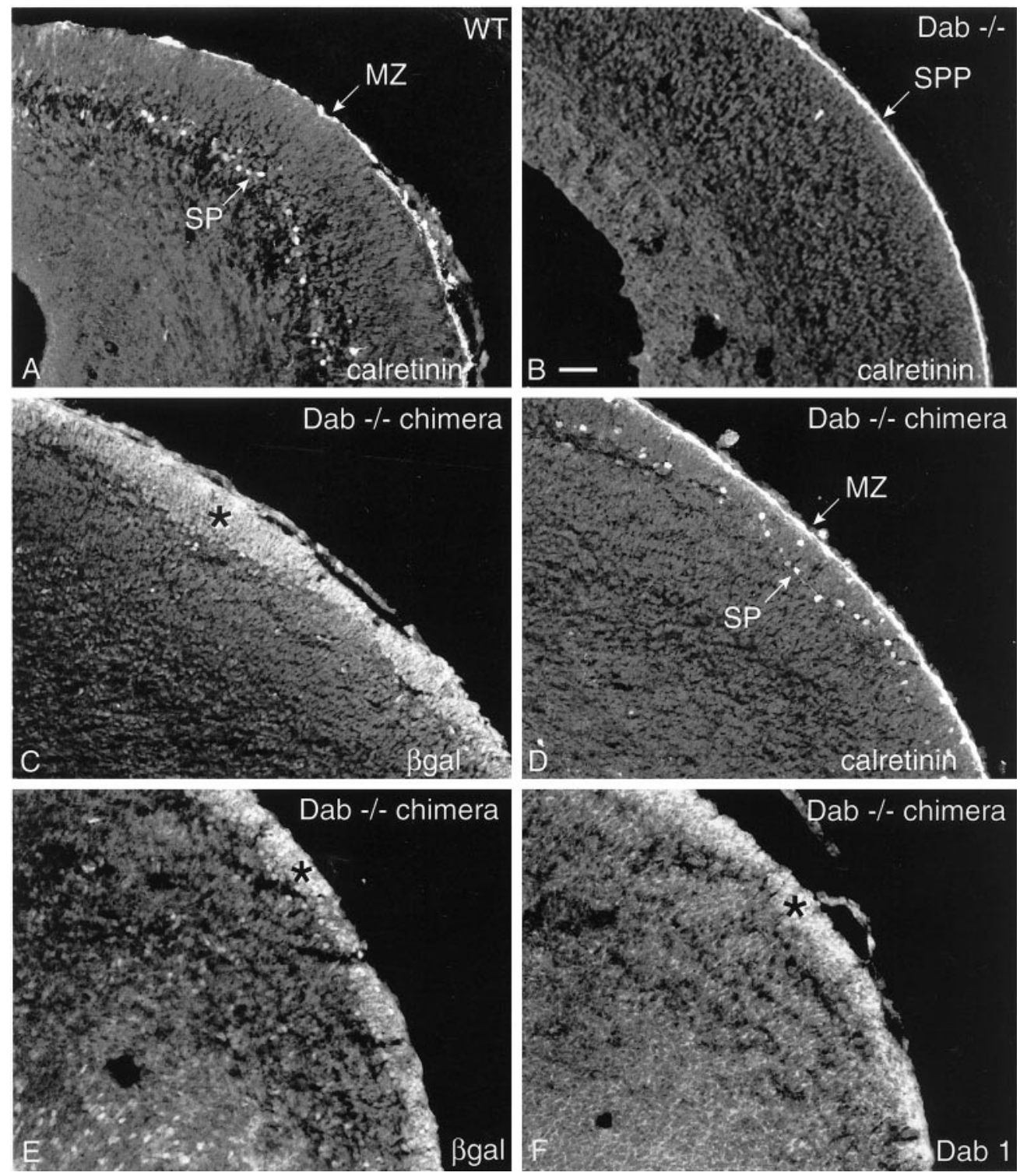

Figure 5. Immunocytochemistry for calretinin shows that the preplate is split in wild-type $(A)$ and $D a b 1^{-1-}$ chimeras $(C, D)$ but not in $D a b 1^{-1-}$ $(B)$. All tissues depicted were obtained from E16.5 neocortices. $A$, Staining for calretinin, a marker for preplate derivatives, shows normal splitting of E16.5 preplate into MZ and SP. B, In mutant $D a b 1^{-/-}$embryos, the preplate fails to split, as indicated by the calretininimmunoreactive SPP. $C, \quad D, \quad$ In Dab1 ${ }^{-/-}$chimeras, the $\beta g a l$-positive supercortex (asterisk) is bounded by calretinin-positive SP cells and the MZ. $E, F$, In adjacent sections (separately stained for $\beta g a l$ and Dab1),

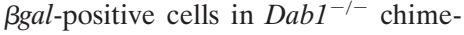
ras express Dab1 in the supercortex (asterisk). Scale bar, $50 \mu \mathrm{m}$. mutant scrambler and Dab1 knock-out mice have been very useful in revealing the central role for Dab1 in neuronal migration and cortical layering (Howell et al., 1997b; Sheldon et al., 1997; Ware et al., 1997). Using chimeras, our results shed additional light on Dab1 gene function in cortical development. By considering the phenotype of $\mathrm{Dab1} 1^{+/+}$cells in the context of a $\mathrm{Dab1} 1^{-/-}$environment, another facet of $D a b 1$ gene function in the Reelin signaling pathway has been exposed. We asked whether the function of Dab1 during cortical cell migration and layering is cell autonomous or whether Dab1 activation produces a non-cellautonomous effect, for example, by regulating the production of cell surface or extracellular molecules that may affect the behavior of other cells. Answers to these questions will assist in identifying the primary role of Dab1 gene function.

The assembly of multiple neuronal layers as a function of development is a complex process, possibly requiring dynamic feedback of positional information between early- and late-born neurons. Various models have been proposed for the molecular control of this process, and they invariably include the Reelin signaling pathway, but other cell surface and cell matrix molecules may also be involved. Confirmation of multiple pathway involvement is evidenced by layering abnormalities in mutant mice for a number of genes, in addition to those described in the Reelin pathway, e.g., p35, Cdk5, and $\alpha 3$ integrin (Gilmore et al., 1998; Kwon and Tsai, 1998; Anton et al., 1999). To further understand this complex process, an important step would be to demonstrate whether or not the key players have interdependent relationships. Whereas the activity of Reelin is clearly non-cell autonomous (Terashima et al., 1986; Yoshiki and Kusakabe, 1998), the results presented here suggest that Dab1 function in the neocortex is cell autonomous. This conclusion is supported by several lines of evidence. First, the mutant environment did not impose a mutant phenotype on the wild-type cells, and, inversely, there was no rescue of the mutant phenotype by wild-type cells. The capacity for radial cell dispersion by $D a b 1^{+/+}$cells in the mutant environment appeared to be unaffected, but columns were abnormal, with the majority of cells dispersing to the superficial part of the column. A minority of $\mathrm{Dab1} 1^{+/+}$neurons was found in the middle and deeper layers of the composite cortex, but the vast majority of wild-type neurons were segregated to the superficial region. Here, they formed a supercortex beneath the pial surface. Second, there was persistence of the mutant pheno- 


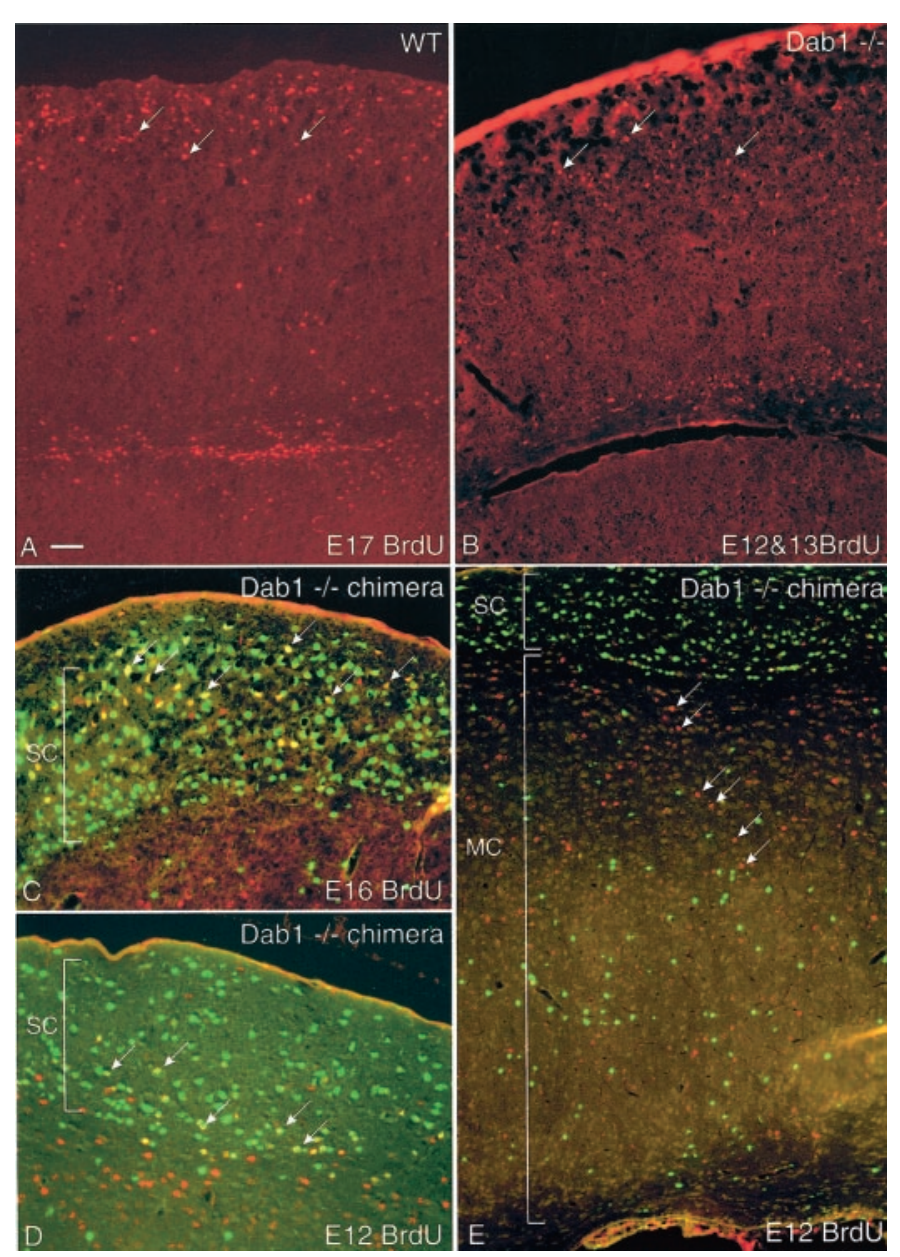

Figure 6. BrdU birth dating shows correct neuronal positioning in wildtype neocortex $(A)$ and $D a b 1^{-1-}$ chimeric supercortex $(C, D)$ but incorrect positions in mutant $D a b 1^{-1-}$ cortex $(B)$. $A$, BrdU labeling of wildtype brains at E17.5 shows staining (arrows) in superficial cortical layers. $B$, In contrast, the neocortex of mutant $\mathrm{Dab1}^{-/-}$mice shows staining in upper layers (arrows), suggesting layer inversion of neurons labeled with BrdU at E12.5 and E13.5. C, In Dab1 $1^{-1-}$ chimeras, $\beta$ gal-positive neurons ( green) labeled with BrdU (red) at E16.5 are found to be positioned in the upper half (yellow, arrows) of the supercortex. This suggests appropriate neuronal layer ordering of late-born neurons. $D, D a b 1^{+/+}$neurons labeled with BrdU at E12.5 (yellow, arrows) are distributed in deeper layers of the supercortex. Mutant Dab1 ${ }^{-1-}$ cells are also labeled with BrdU (red) at E12.5, and they are mostly segregated in an inverted manner in the upper parts of the mutant cortex, just beneath the supercortex. $E$, Low-power view shows that mutant $D a b 1^{-1-}$ cells labeled with BrdU (red, arrows) at E12.5 are inappropriately distributed to the upper one-third of the mutant cortex $(M C)$, despite the presence of the wild-type supercortex above (SC). Scale bar: $A, B, 75 \mu \mathrm{m} ; C, D, 48 \mu \mathrm{m} ; E, 24 \mu \mathrm{m}$.

type in the MZ, i.e., infiltration by a large number of mutant cell bodies despite the close proximity of the wild-type supercortex, again implying lack of rescue. Although the MZ was densely populated by mutant cells, few wild-type cells bodies were seen here, consistent with the notion that the wild-type preplate has been properly split and most of the wild-type cells have withdrawn from the MZ. This interpretation of cell-autonomous behavior is substantiated by the presence of calretinin-positive subplate cells underneath the chimeric supercortical plate. Evidently, despite the presence of wild-type cells, the mutant preplate had failed to split, otherwise a second calretinin-positive subplate would be observed below the mutant cortical plate. On the other hand, the observable subplate contains a mixture of both mutant and wild-type cells, suggesting that some mutant cells may have responded to the subplate-splitting cues and have assembled in the correct location with respect to the wild-type, but not mutant, cortical plate. Most likely, mutant cell bodies seen in the composite MZ (Fig. $2 F$ ) represent the bulk of the ectopically displaced subplate cells from the unsplit mutant preplate (Rice et al., 1998).

Within the supercortex, the dense packing of cells made it difficult to distinguish between cortical layers on the basis of cellular morphology or size, but birth-dating experiments using BrdU and staining with calbindin, a marker of upper layer neurons (Demeulemeester et al., 1989; van Brederode et al., 1991), indicate that they have formed in the "correct" inside-out order. Furthermore, the presence of an appropriately localized subplate in the embryo, and later in the adult, the extensive myelination in the secondary "white matter," suggest that restoration of Dab1 function has promoted assembly of a separate cortex, despite it being sandwiched between mutant cortical tissue. However, there were a number of unusual features in the supercortex compared with the normal cortex. First, the supercortex was overwhelmingly pyramidal in character as evidenced by double-staining for Emx1. On the other hand, staining for GABA, a marker of inhibitory neurons, revealed hardly any $D a b 1^{+/+}$GABAergic cells inside the supercortex. The few GABAergic cells present in the supercortex were invariably $\mathrm{Dab1} 1^{-1-}$ in genotype (Fig. 3G, arrowheads). Gauging from a similar density of mutant GABAergic cells in the underlying mutant cortex, their presence in the supercortex may simply reflect sharing of a common cortical space. Although $\mathrm{Dab} 1^{+/+}$GABAergic neurons were hardly seen in the supercortex, they were freely present beneath (Fig. $3 G$, arrows), mixed in with other cells of the mutant cortex. This finding raises the possibility that the supercortical environment, bounded between subplate and MZ, may be especially conducive to the pyramidal phenotype (Gilmore et al., 1998). However, this fails to account for the under-representation of wild-type GABAergic cells in the supercortex. Perhaps interneuron migration, which is primarily tangential and mostly from underlying striatum (Anderson et al., 1997, 2001; Tan et al., 1998), may be unresponsive to Reelin signaling and their positions mediated by other mechanisms that are non-cell autonomous with respect to Dab1. It would be interesting for future studies to determine whether the function of Dab1 extends equally to both pyramidal and nonpyramidal cells.

Another unusual feature of the supercortex was the extraordinary compression of the layers at the expense of neuropil space. Furthermore, the supercortex was invariably positioned in the upper part of the composite cortex with a minor but still substantial population of straggling $\beta$ gal-positive cells in the middle and deeper layers. The superficial location of the supercortex may be attributable to space constraints imposed by $\mathrm{Dab1} 1^{-1-}$ cells in an overpopulated cortex, resulting in upward pressure exerted on the undersurface of the supercortex, preventing their downward expansion into the deeper layers. Therefore, straggling cells, many of which are pyramidal neurons, may also represent incomplete attempts to fill the depth of cortical space.

Alternatively, the asymmetric placement of the supercortex may simply reflect increased affinity of wild-type neurons for a source of Reelin near the pial surface. This observation invites speculation for a mechanistic role of Dab1 in neuronal positioning. One model suggests temporary increases in cell-cell adhesion at the Reelin-cortical plate interface as incoming neurons 


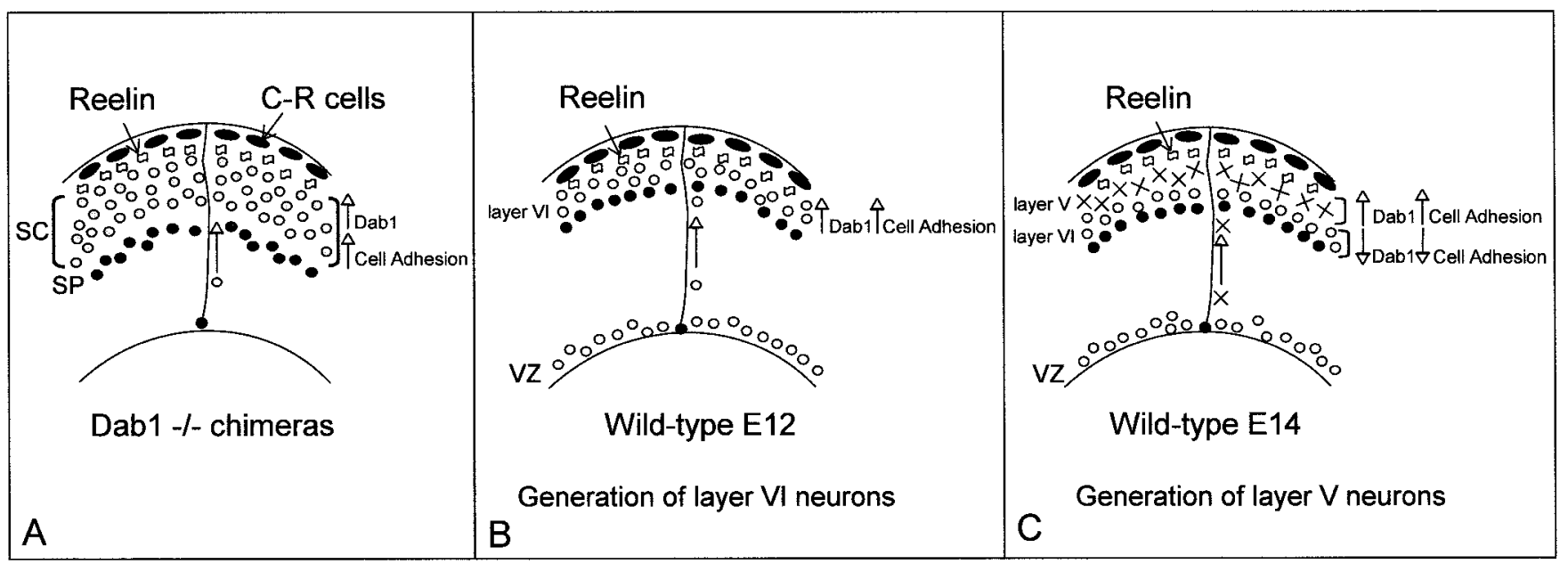

Figure 7. A, Proposed model to account for supercortex $(S C)$ formation from increased cell adhesion among Dab1 cells in a Dab1 ${ }^{-/-}$environment. In this model, an SP is formed beneath the supercortex from cell-autonomous function of Dab1 cells. $C$ - $R$ cells, Cajal-Retzius cells. $B, C$, Model to suggest how dynamic changes in Dab1 activity and degradation may account for correct neuronal positioning among successive waves of migrating neurons. In this example, layer VI neurons generated at E12 are attracted to a Reelin source, leading to increasing cell adhesion mediated by Dab1 as neurons approach the marginal zone. Dab1 activation in layer VI cells is followed by Dab1 degradation, leading to decreased cell-cell adhesion among layer VI neurons. At the same time, arriving layer V neurons (generated at E14) show increasing Dab1 activity as they respond to Reelin in the marginal zone, causing increased cell-cell adhesion and enabling them to migrate past layer VI cells.

expressing high levels of Dab1 are activated by Reelin (Fig. 7A). Under normal circumstances, a momentary increase in cell adhesion would draw the most recent arrivals past preexisting neurons (displacing them in the process) to the MZ (Fig. 7B). After arrival near the MZ, Reelin binds to other surface molecules (e.g., $\alpha 3 \beta 1$ integrin) to initiate neuronal de-adhesion and detachment from radial glia (Dulabon et al., 2000). Reiteration of this process, involving successive waves of Dab1-expressing cells, may explain how incoming cohorts of neurons can leapfrog over older and less adhesive neurons whose Dab1 may be downregulated or degraded (D'Arcangelo et al., 1999) (Fig. 7C). What may be the mechanism for increased cell adhesion after Dab1 activation? One lead is available from recent work with p35-activating proteins. The $\mathrm{p} 35$ protein is a regulator of $\mathrm{Cdk} 5$ kinase, and mutations in both proteins result in abnormalities of cortical layering. It has been demonstrated that increased kinase activity leads to decreased cell adhesion because of disruption of $\mathrm{N}$-cadherin- $\beta$-catenin complexes (Kwon et al., 2000). Although a direct link between Dab1 and p35-Cdk5 kinase remains elusive, it has been suggested that one effect of Reelin signaling is to inhibit p35-Cdk5 kinase activity in newly arriving neurons, leading to increased $\mathrm{N}$-cadherin-mediated adhesion (Homayouni and Curran, 2000).

Finally, the distribution of the straggling $\beta$ gal-positive cells at midcortical levels deserves additional comment. These $D a b 1^{+/+}$ cells may have failed to make it to the supercortex, suggesting that there are defects in the $D a b 1^{-/-}$environment that may not be fully overcome by a $D a b 1^{+/+}$genotype. This is suggestive of non-cell-autonomous behavior mediated by structures that normally facilitate neuronal migration. One possibility is that radial glia in the mutant cortex may be defective, as has been reported in reeler mice (Pinto-Lord et al., 1982; Hunter-Schaedle, 1997), causing obstruction of neuronal migration affecting both mutant and wild-type neurons. The other possibility is that failure of $D a b 1^{-1-}$ neurons to detach from radial glia may have caused a structural blockade imposed by malpositioned $D a b 1^{-1-}$ neurons (Dulabon et al., 2000). However, the fact that the bulk of wild- type neurons have somehow been able to migrate past mutant neurons would argue against a log-jam hypothesis. Nonetheless, straggling wild-type neurons may have behaved like mutant neurons and been blocked in their migratory journey, perhaps because of sharing of glial fibers with mutant neurons that failed to detach. Thus, although the main conclusion of the present study points to a cell-autonomous role for Dab1, it needs to be tempered by the possibility of non-cell-autonomous behavior for neurons that do not insert into the supercortex.

\section{REFERENCES}

Anderson SA, Eisenstat DD, Shi L, Rubenstein JLR (1997) Interneuron migration from basal forebrain to neocortex: dependence on Dlx genes. Science 278:474-476.

Anderson SA, Marin O, Horn C, Jennings K, Rubenstein JL (2001) Distinct cortical migrations from the medial and lateral ganglionic eminences. Development 128:353-363.

Angevine JB, Sidman RL (1961) Autoradiographic study of cell migration during histogenesis of the cerebral cortex in the mouse. Nature 192:766-768.

Anton ES, Kreidberg JA, Rakic P (1999) Distinct functions of $\alpha 3$ and $\alpha \mathrm{V}$ integrin receptors in neuronal migration and laminar organization of the cerebral cortex. Neuron 22:277-289.

Caviness Jr VS (1982) Neocortical histogenesis in normal and reeler mice: a developmental study based upon $[3 \mathrm{H}]$ thymidine autoradiography. Brain Res 256:293-302.

Caviness Jr VS, Sidman RL (1973) Time of origin or corresponding cell classes in the cerebral cortex of normal and reeler mutant mice: an autoradiographic analysis. J Comp Neurol 148:141-151.

Cecchi C, Boncinelli E (2000) Emx homeogenes and mouse brain development. Trends Neurosci 23:347-352.

Chan C-H, Godinho LN, Thomaidou D, Tan S-S, Gulisano M, Parnavelas JG (2001) Emxl is a marker for pyramidal neurons of the cerebral cortex. Cereb Cortex, in press.

D'Arcangelo G, Miao GG, Chen SC, Soares HD, Morgan JI, Curran T (1995) A protein related to extracellular matrix proteins deleted in the mouse mutant reeler. Nature 374:719-723.

D'Arcangelo G, Nakajima K, Miyata T, Ogawa M, Mikoshiba K, Curran $\mathrm{T}$ (1997) Reelin is a secreted glycoprotein recognized by the CR-50 monoclonal antibody. J Neurosci 17:23-31.

D'Arcangelo G, Homayouni R, Keshvara L, Rice DS, Sheldon M, Curran $\mathrm{T}$ (1999) Reelin is a ligand for lipoprotein receptors. Neuron 24:471-479.

Demeulemeester H, Vandesande F, Orban GA, Heizmann CW, Pochet R (1989) Calbindin D-28K and parvalbumin immunoreactivity is confined to two separate neuronal subpopulations in the cat visual cortex, 
whereas partial coexistence is shown in the dorsal lateral geniculate nucleus. Neurosci Lett 99:6-11.

Dulabon L, Olson EC, Taglienti MG, Eisenhuth S, McGrath B, Walsh CA, Kreidberg JA, Anton ES (2000) Reelin binds $\alpha 3 \beta 1$ integrin and inhibits neuronal migration. Neuron 27:33-44.

Fonseca M, del Rio JA, Martinez A, Gomez S, Soriano E (1995) Development of calretinin immunoreactivity in the neocortex of the rat. J Comp Neurol 361:177-192.

Gilmore EC, Ohshima T, Goffinet AM, Kulkarni AB, Herrup K (1998) Cyclin-dependent kinase 5-deficient mice demonstrate novel developmental arrest in cerebral cortex. J Neurosci 18:6370-6377.

Goldowitz D, Cushing RC, Laywell E, D’Arcangelo G, Sheldon M, Sweet HO, Davisson M, Steindler D, Curran T (1997) Cerebellar disorganization characteristic of reeler in scrambler mutant mice despite presence of reelin. J Neurosci 17:8767-8777.

Goto K, Kurihara T, Takahashi Y, Kondo H (1990) Expression of genes for the myelin-specific proteins in oligodendrocytes in vivo demands the presence of axons. Neurosci Lett 117:269-274.

Gulisano M, Broccoli V, Pardini C, Boncinelli E (1996) Emx1 and Emx2 show different patterns of expression during proliferation and differentiation of the developing cerebral cortex in the mouse. Eur J Neurosci 8:1037-1050.

Hawkes R, Beierbach E, Tan S-S (1999) Granule cell dispersion is restricted across transverse boundaries in mouse chimeras. Eur J Neurosci 11:3800-3808.

Hiesberger T, Trommsdorff M, Howell BW, Goffinet A, Mumby MC, Cooper JA, Herz J (1999) Direct binding of Reelin to VLDL receptor and ApoE receptor 2 induces tyrosine phosphorylation of disabled-1 and modulates tau phosphorylation. Neuron 24:481-489.

Homayouni R, Curran T (2000) Cortical development: Cdk5 gets into sticky situations. Curr Biol 10:R331-R334.

Howell BW, Gertler FB, Cooper JA (1997a) Mouse disabled (mDab1): a Src binding protein implicated in neuronal development. EMBO J 16:121-132.

Howell BW, Hawkes R, Soriano P, Cooper JA (1997b) Neuronal position in the developing brain is regulated by mouse disabled-1. Nature 389:733-737.

Howell BW, Herrick TM, Cooper JA (1999) Reelin-induced tryosine phosphorylation of disabled 1 during neuronal positioning. Genes Dev 13:643-648.

Howell BW, Herrick TM, Hildebrand JD, Zhang Y, Cooper JA (2000) Dab1 tyrosine phosphorylation sites relay positional signals during mouse brain development. Curr Biol 10:877-885.

Hunter-Schaedle KE (1997) Radial glial cell development and transformation are disturbed in reeler forebrain. J Neurobiol 33:459-472.

Kwon YT, Tsai LH (1998) A novel disruption of cortical development in p35(-/-) mice distinct from reeler. J Comp Neurol 395:510-522.

Kwon YT, Gupta A, Zhou Y, Nikolic M, Tsai LH (2000) Regulation of N-cadherin-mediated adhesion by the p35/Cdk5 kinase. Curr Biol 10:363-372.

Ogawa M, Miyata T, Nakajima K, Yagyu K, Seike M, Ikenaka K, Yamamoto H, Mikoshiba K (1995) The reeler gene-associated antigen on Cajal-Retzius neurons is a crucial molecule for laminar organization of cortical neurons. Neuron 14:899-912.

Pinto-Lord MC, Evrard P, Caviness VS (1982) Obstructed neuronal migration along radial glial fibers in the neocortex of the reeler mouse: a Golgi-EM analysis. Dev Brain Res 4:379-393.

Rakic P (1974) Neurons in rhesus monkey visual cortex: systematic relation between time of origin and eventual disposition. Science $183: 425-427$.
Reese BE, Necessary BD, Tam PPL, Faulkner-Jones B, Tan S-S (1999) Clonal expansion and cell dispersion in the developing mouse retina. Eur J Neurosci 11:2965-2978.

Rice DS, Curran T (1999) Mutant mice with scrambled brains: understanding the signaling pathways that control cell positioning in the CNS. Genes Dev 13:2758-2773.

Rice DS, Sheldon M, D’Arcangelo G, Nakajima K, Goldowitz D, Curran $\mathrm{T}$ (1998) Disabled-1 acts downstream of Reelin in a signaling pathway that controls laminar organization in the mammalian brain. Development 125:3719-3729.

Rossant J, Spence A (1998) Chimeras and mosaics in mouse mutant analysis. Trends Genet 14:358-363.

Shindler KS, Roth KA (1996) Double immunofluorescent staining using two unconjugated primary antisera raised in the same species. J Histochem Cytochem 44:1331-1335.

Senzaki K, Ogawa M, Yagi T (1999) Proteins of the CNR family are multiple receptors for Reelin. Cell 99:635-647.

Sheldon M, Rice DS, D’Arcangelo G, Yoneshima H, Nakajima K, Mikoshiba K, Howell BW, Cooper JA, Goldowitz D, Curran T (1997) Scrambler and yotari disrupt the disabled gene and produce a reelerlike phenotype in mice. Nature 389:730-733.

Sprinkle TJ (1989) 2'3'-cyclic nucleotide 3'-phosphodiesterase, an oligodendrocyte-Schwann cell and myelin-associated enzyme of the nervous system. Crit Rev Neurobiol 4:235-301.

Sturm KS, Berger CN, Zhou SX, Dunwoodie SL, Tan S-S, Tam PPL (1997) Unrestricted lineage differentiation of parthenogenetic EScells. Dev Gene Evol 206:377-388.

Tan S-S, Williams EA, Tam PPL (1993) X-chromosome inactivation occurs at different times in different tissues of the post-implantation mouse embryo. Nat Genet 3:170-174.

Tan S-S, Kalloniatis M, Sturm K, Tam PPL, Reese BE, Faulkner-Jones BE (1998) Separate progenitors for radial and tangential cell dispersion during development of the cerebral neocortex. Neuron 21:295-304.

Terashima T, Inoue K, Inoue Y, Yokoyama M, Mikoshiba K (1986) Observations on the cerebellum of normal-reeler mutant mouse chimera. J Comp Neurol 252:264-278.

Thompson RJ (1992) 2'3'-cyclic nucleotide-3'-phosphohydrolase and signal transduction in central nervous system myelin. Biochem Soc Trans 20:621-626.

Trommsdorff M, Gotthardt M, Hiesberger T, Shelton J, Stockinger W, Nimpf J, Hammer RE, Richardson JA, Herz J (1999) Reeler/ Disabled-like disruption of neuronal migration in knockout mice lacking the VLDL receptor and ApoE receptor 2. Cell 97:689-701.

van Brederode JF, Helliesen MK, Hendrickson AE (1991) Distribution of the calcium-binding proteins parvalbumin and calbindin-D28k in the sensorimotor cortex of the rat. Neuroscience 44:157-171.

Vogel US, Reynolds R, Thompson RJ, Wilkin GP (1988) Expression of the $2^{\prime}, 3^{\prime}$-cyclic nucleotide $3^{\prime}$-phosphohydrolase gene and immunoreactive protein in oligodendrocytes as revealed by in situ hybridization and immunofluorescence. Glia 1:184-190.

Vogt-Weisenhorn DM, Weruaga-Preito E, Celio MR (1994) Localization of calretinin in cells of layer I (Cajal-Retzius cells) of the developing cortex of the rat. Dev Brain Res 82:293-297.

Ware ML, Fox JW, Gonzalez JL, Davis NM, Lambert de Rouvroit C, Russo CJ, Chua Jr SC, Goffinet AM, Walsh CA (1997) Aberrant splicing of a mouse disabled homolog, mdab1, in the scrambler mouse. Neuron 19:239-249.

Yoshiki A, Kusakabe M (1998) Cerebellar histogenesis as seen in identified cells of normal-reeler mouse chimeras. Int J Dev Biol 42:695-700. 